\title{
Black Postcolonial Communities in a Globalised World as Articulated in the Work of Paul Gilroy and Edouard Glissant: A Comparative Analysis
}

\section{Sam Coombes}

\section{(2) OpenEdition}

1 Journals

Electronic version

URL: https://journals.openedition.org/ces/5168

DOI: $10.4000 /$ ces. 5168

ISSN: 2534-6695

\section{Publisher}

SEPC (Société d'études des pays du Commonwealth)

\section{Printed version}

Date of publication: 1 April 2014

Number of pages: 12-18

ISSN: 2270-0633

\section{Electronic reference}

Sam Coombes, "Black Postcolonial Communities in a Globalised World as Articulated in the Work of Paul Gilroy and Edouard Glissant: A Comparative Analysis", Commonwealth Essays and Studies [Online], 36.2 | 2014, Online since 15 April 2021, connection on 19 July 2021. URL: http:// journals.openedition.org/ces/5168 ; DOl: https://doi.org/10.4000/ces.5168

\section{(c) (i) $\ominus$}

Commonwealth Essays and Studies is licensed under a Licence Creative Commons Attribution - Pas d'Utilisation Commerciale - Pas de Modification 4.0 International. 


\section{Black Postcolonial Communities in a Globalised World as Articulated in the Work of Paul Gilroy and Edouard Glissant: A Comparative Analysis}

This article seeks areas of reciprocity and overlap between the theories of Gilroy and Glissant of the last twenty-five or so years. Its point of departure is the conviction that both authors progress from a focus on specific black communities to viewing the black postcolonial condition in general as a harbinger for, and paradigmatic of, the leading cultural trends which characterise today's era of globalisation.

I want to emphasize the decidedly transnational character of modes of production, social movements and informal exchanges $[\ldots]$ the example offered by the history of the black Atlantic world [...] contains a fluid and dynamic cultural system that escapes the grasp of nation-states and national conceptions of political and economic development.

Paul Gilroy Small Acts

Thought resulting from intermixing ["métissage"], and from the uncertain value not only of cultural intermixing but, more importantly, from cultures of intermixing, which perhaps protect us from the limitations and intolerance that lie in wait for us, and will open up new spaces of relation. ${ }^{1}$ [My translation]

Edouard Glissant, Traité du tout-monde

Paul Gilroy (1956 - ) and Edouard Glissant (1928-2011) have theorised both the postcolonial condition of the black communities they originated in, and also that condition in so far as they regard it as a harbinger, and even a paradigm, for rapidly evolving relationships between diverse cultures in the context of globalisation. They evidently share a number of key characteristics: both thinkers are either from, or have strong links to, West Indian postcolonial communities. The cultural origins of both lie in former colonies of major European colonial nations, Britain and France, and each has been trying to reinterpret and negotiate the colonial legacy in a myriad of ways. This article focuses on Gilroy and Glissant not just as individual thinkers, each with his own outlook and vision, but also the ways in which these visions highlight broader issues of the British and French colonial inheritances. Far from reducing either thinker to his own context, this article intends to highlight the constant dialectical interplay between individual and cultural context, and therefore to try to elucidate this complex, multiple-facetted issue: that of two postcolonial intellectuals from two parallel colonial situations, both of whom have been trying to make sense not just of the histories of their own communities, but also of where those communities stand today in contemporary cosmopolitan western societies.

1. 'La pensée du métissage, de la valeur tremblante non seulement des métissages culturels mais, plus avant, des cultures de métissage, qui nous préservent peut-être des limites ou des intolérances qui nous guettent, et nous ouvriront de nouveaux espaces de relation" (25). 
It is worth indicating at the outset of this analysis that there are many contrasts and differences between the intellectual orientations of Gilroy and Glissant, which complicates an entirely straightforward comparison of their theories. I will briefly list a few of these now in order to highlight to what extent these disparities are revealing of contrasting colonial legacies. If one sets aside the fact that Glissant spent much of the last part of his life living as an expatriate in New York, he and Gilroy were writing in rather different postcolonial situations, and therefore fundamentally about communities whose preoccupations and demands were rather divergent. Whereas Gilroy's case is very clearly that of an intellectual partly originating from, and certainly identifying with, the British West Indian community i.e., a community which is not simply postcolonial but also a diasporic immigrant community, Glissant was born in the French Département of Martinique. The postcolonial status of the French Départements d'Outre-Mer is very controversial with referenda having been held as recently as 2010, when Martinique voted massively not to take further steps in the direction of outright independence from France. $^{2}$

Glissant's theoretical works are of a much more philosophical nature than Gilroy's, which are rooted in the more positivist, less hypothetical field of sociology. Even though it would be fair to say that Gilroy's writing of the last twenty years is about as conjectural $^{3}$ as English-language theoretical writing ever seems to be, Glissant's speculative approach is much more clearly inspired by the Continental intellectual tradition. Indeed there is paradoxically a quintessential Frenchness not just to Glissant's intellectual and publishing itinerary, but also to that of leading, Glissant-inspired Creolists - Patrick Chamoiseau in particular. Glissant's works are almost all published by Gallimard and in French as are those of Chamoiseau. In the latter's case, this fact appears to stand in stark contradiction with an avowed aim to re-kindle and promote a putatively lost Creole quasi-oral literary culture. Glissant's work does not demonstrate this kind of performative contradiction because, like Aimé Césaire and indeed differently Frantz Fanon before him, he never publically made nationalist claims for Creole culture the centrepiece of his theory. In Poétique de la Relation, Glissant dissociates himself explicitly from the Creolists, presenting the latters' thinking as unnecessarily essentialist because involving

an attempt to get at Being. But that would constitute a step backward in comparison with how creolizations can function. We propose neither humanity's Being nor its models. We are not prompted solely by the defining of our identities but by their relation to everything possible as well. (90, italics in the original]

Nevertheless, it would be reductive to see in Glissant's Frenchness, like Chamoiseau's, the mere consequence of a neo-colonial inheritance and inspiration. It was central to the intellectual and real-world fabric of his life: he published in Paris, not in Fort de France. He wrote in the language not just of a former colonial oppressor, but in that of what he and his Antillean independentist colleagues have long considered to be a country that has remained their neo-colonial master to the present day. This highly paradoxical situation is far from being specific to Glissant and Chamoiseau though. It is in

2. On the 10th January 2010, Martiniquans voted by a landslide $79.3 \%$ to reject the proposed "Article 74 " which would have given the island greater autonomy from France.

3. Gilroy's theoretical writing is characterised by a marked tendency to diverge from the positivist exposition of argumentation most commonly employed in Anglophone academic writing. Its conceptual density, intuitiveness, and allusive delivery suggest an affinity with the Continental tradition on Gilroy's part. 
fact representative of the situation in which the majority of Francophone Caribbean intellectual-writers have found themselves since the implementation of départmentalisation in 1946. Indeed, in a broader sense, the ambivalence of struggling with, and sometimes against, Frenchness whilst being French typifies the postcolonial condition of Francophone Caribbean societies as a whole.

As black postcolonial citizens who also happen to be intellectuals, Gilroy and Glissant occupy an inside/outside position, and it is worth briefly pondering just exactly what this amounts to in each case. Both are diasporians - a fact which is central in their theoretical work, whether it appears in the form of the idea of the black Atlantic or that of creoleness and creolisation. As a result, they perceive themselves (whether this is just a subjective or community-based perception or a reality) as either coming from an outside or elsewhere in relation to the majoritarian community of the countries they inhabit. Yet, on the one hand Gilroy identifies with an immigrant community whilst, on the other hand, he has long been situated inside British society because he has lived and worked in the UK. ${ }^{4}$ Glissant, after his student years, was no longer an immigrant in France and, technically speaking at least, he was not part of a minority community. But, Martinique being an integral part of France meant that Glissant also experienced the profound cultural alienation which colonial subjects felt in times past. In short, what is outside and what is inside can be identified fairly straightforwardly in the case of Gilroy, however complex and difficult the issues he raises may be to analyse. But the case of a Martinican such as Glissant is more ambivalent: it would seem almost impossible in this instance to demarcate the inside from the outside or vice versa. The Martinican situation is a perpetual inside-outside/outside-inside condition to the point that the two concepts almost cease to have any distinct meaning in relation to each other. What is inside is simultaneously outside and what is outside simultaneously inside.

In spite of blatant differences in their origins and intellectual approaches, I believe that there is much to be gained from a comparative analysis of Gilroy and Glissant. ${ }^{5}$ The theories they have elaborated since the late 1980s will be the central focus in what follows although it is obvious from the points I have already made that I do not make any stark separation between the sphere of ideas and that of cultural, social and political realities or indeed that of subjective lived experience. The constant dialectical interplay between these spheres cannot be overlooked in the case of postcolonial authors in general, and certainly not in the cases of Gilroy and Glissant. Their theories have been so explicitly concerned with social phenomena that any endeavour to analyse them as configurations in the sphere of ideas alone would be detrimental to their understanding. I should add, however, that whilst this point is quite obvious in the case of the initially sociologically-oriented Gilroy, it is perhaps less so with the more philosophical Glissant. Indeed, a surprising amount of criticism referring to, or focused onto, his work has managed to convey the impression, perhaps as much inadvertently as by design, that

4. Indeed, Gilroy's first two books, The Empire Strikes Back - Race and Racism in '70s Britain (1982, co-author) and There Ain't No Black In the Union Jack: The Cultural Politics of Race and Nation (1987) are squarely focused on the social condition of the Black British community.

5. Chris Bongie's Friends and Enemies: The Scribal Politics of Post/colonial Literature contains a number of salient passages which relate the ideas of Glissant to those of Gilroy, thereby laying the ground for such a comparative analysis. See Bongie (2008), 59-61, 87, 136-7. 
concepts like "créolisation" and Relation" could be discussed largely in isolation from matters pertaining to the social, cultural and political context of the 1980s.

Glissant had of course had a lengthy career before that time, and also wrote literary as well as theoretical works. However, Gilroy being the younger author of the two, does not have publications dating back beyond the late 1980s. Moreover, it is of particular interest to analyse the manifold ways in which these two authors' writings of the last two decades address not just issues of cultural difference within contemporary Western societies, but also the very nature of cosmopolitanism. In short, I believe Gilroy's and Glissant's theoretical analyses speak to the whole of the social sciences today, and not just to specialists in postcolonial studies, sociology or philosophy. Moreover, both thinkers also incarnate a characteristic of what Gilroy identifies as an important trait of African-descended thought, namely a strong syncretic tendency to cross boundaries between disciplines, to conceptualise holistically rather than to compartmentalise. Speaking of this tendency, Gilroy observes that:

The writers and political thinkers generated within the black Atlantic tradition have produced a rich body of work in which reflection on nationality, hybridity, independence, syncretism and self-determination have been acknowledged as central political and philosophical questions for something like two hundred years. (Small Acts 71)

Gilroy opens the first chapter of his now seminal book The Black Atlantic (1993) with two quotations, one from Nietzsche, and the second from Glissant on the subject of modernity. In it, Glissant states that without us being aware of modernity it cannot really exist. References and/or quotations drawn from Glissant's Discours Antillais (1981) appear on three other occasions in the same work. Nowhere in Gilroy's more recent books is Glissant referred to at all, which would suggest that his engagement with his more senior contemporary's thought was limited to Le Discours antillais in which Glissant remained focused on Caribbean issues. Gilroy's subsequent disinterest is significant when one considers how long it took for Glissant to be read with any seriousness in the Anglophone world. Gilroy was not alone. What though does the Gilroy of 1993 make of this predecessor who was still relatively little known, probably because hardly translated, in the Anglophone context? Gilroy credits Glissant with having "contributed so much to the emergence of a creole counter-discourse" in a chapter entitled "The Black Atlantic as a Counterculture of Modernity" (The Black Atlantic 31). It is then quite evident that Gilroy regards Glissant as an important precursor for the theory he is himself proposing. He views Glissant's "Creole counter-discourse" as an act of cultural resistance to neo-colonial hegemony just as his own "black Atlantic" represents the flip side of Western modernity, implying a critique of it undertaken from within as well as from outside. Black communities living in the Western world have been dragged by European colonialism into a modernity the intrinsic value of which is highly dubious,

6. These are arguably the two most central concepts in Glissant's theoretical writings. Creolisation takes place when two or more cultures come into contact and a productive exchange results. For Glissant, creolisation does not involve a full synthesis of the two or more phenomena interacting. Each phenomenon remains distinct from the other(s). The term "Relation" designates the manifold interrelationships between phenomena, be they situated locally or transnationally, that characterise and also facilitate cultural interaction in today's world.

7. The expression "black Atlantic" has both geographical and cultural connotations, encompassing for Gilroy all the places on either side of the Atlantic where black communities and cultures settled and developed in the aftermath of slavery and colonial exploitation. 
Gilroy believes, but the residue of their non-Western origins endures to constitute an ongoing oppositional narrative resisting the prevailing Western master narrative.

Gilroy is surely right to suggest that Glissant's viewpoint and his own are consonant in this respect. The shared desire to encourage a counterculture or counter-discourse would clearly appear to be a consequence of a feeling of marginalisation in today's Western societies. Writing about Martinique, Glissant addressed the neo-colonial situation of a community ruled by a distant European state, and economically still very much under the thumb of the békés, today's descendants of the white plantation owners. In Britain, the black community, Gilroy argues, has been in recent years the butt of a "new racism," i.e., a form of discrimination founded on the view that non-whites are culturally different and therefore unable to integrate into British society. Whether in Martinique or in Britain, the black communities are not accorded a fully equal status with the majoritarian white community.

Gilroy's and Glissant's subjects are, like the authors themselves, fundamentally diasporic, the black British being mostly of immigrant heritage, and Francophone West Indian culture being the result of what Glissant calls "créolisation," a term by which Glissant designates the process involving two or more cultures coming into contact and forming a new configuration as a consequence of the displacement or migration of certain communities (Poétique du divers 55). Creole culture could not have come into being without the arrival of migrant communities, whether forced or by choice, in the West Indies. Black British communities and their Creole-speaking counterparts share a pronounced transnational character, a transversality encapsulated in Glissant's adoption of the Deleuzian rhizomatic conception of identity which rejects the idea of a unitary root. In Gilroy's work, the putative "black Atlantic" designates an imagined community, to use Benedict Anderson's term, which is not that of any given nation but rather of diverse black communities which, over and above the matter of racial appurtenance, share a commonality of experience. Anderson attempts to account for new types of transnational connections which developments in transport and communications technologies have made possible. If his theory importantly anticipates some of the leading tendencies of today's globalised era, then it is best understood as having been pre-figured by the black Atlantic and by the process of West Indian creolisation as these phenomena are set out in the work of Gilroy and Glissant respectively. Gilroy and Glissant, it must be remembered, have both been critical of globalisation in its contemporary form, but the alternative visions they propose nevertheless centrally retain the idea of transnational networks and communities.

Gilroy draws quite frequently on the theories of the African-American intellectual W. E. B. DuBois, in particular on his concept of the "double consciousness" (Dusk of Dawn 639-70) experienced by African American citizens when they feel both part of the West and not of the West at the same time. There is no concept equivalent to this in Glissant's work precisely because, as I highlighted earlier, he did not live out most of his life as a member of a racial minority within a Western nation, Martinique being distant from mainland France. Glissant's take on minoritarianism is expressed rather in the form of a defence of the local in the face of the universalising tendencies of French neo-colonialism on the one hand and the homogenising drive of Anglo-American-led globalisation on the other. The defence of the local is expressed through the concept of "opacité" which stands in opposition to transparency and universalism. As such it 
can be related to Glissant's valueing of difference or "le divers," as he prefers to term it (Poétique du divers 54). Minoritarian communities such as the Francophone Antillean ones should have a right to a particular, local cultural identity which does not have to account for itself to either the French state or the wider world, Glissant argues. Colonial and neo-colonial forces rely in part on an insistence on transparency as a pretext for subordinating such communities and ironing out their particularities.

Gilroy's and Glissant's respective takes on the cultural difference of minoritarian communities share a marked scepticism about the value of Western modernity, the development of which they identify as having been integrally linked with the colonial project historically. They also converge on a countervailing defence of the idea that black communities represent, even incarnate, a critical stance against Western modernity by their very natures as cultural beings. Ultimately, they both agree that this defence can and should be paradigmatic of a wider political resistance in the West to imperialist and neo-imperialist tendencies, in whatever forms the latter should manifest themselves.

Earlier I made a leap in passing from talking about Gilroy's writing as predominantly concerned with black British communities to stating that it is concerned with transnational imagined communities of black peoples. This transition reflects a very real chronological progression in Gilroy's work from one of his earliest books, There Ain't No Black in the Union Jack to notably The Black Atlantic but also Small Acts, and ultimately his broader analyses of culture and cosmopolitanism in more recent works like Between Camps and After Empire published at the turn of the twenty-first century. A similar thematic progression can actually be identified in Glissant's work if one considers the evolution from the Martinique-focused Discours Antillais to Poétique de la Relation and his more recent essays such as Traité du Tout-Monde and L'Intraitable beauté du monde: Adresse à Barack Obama, all of which present creolisation and Relation in a more international perspective. A manifest desire to extend their reflections beyond the immediate concerns of localised racial or cultural groups in order to address matters of wider significance is apparent in both Gilroy and Glissant. However, this thematic development is achieved in their respective oeuvres without sacrificing coherence. The condition of the localised creolised and/or diasporic group or community is often extrapolated from to yield a new working paradigm for cosmopolitan Western societies in the age of globalisation. In Glissant, creolisation which has been so central to the constitution of subjects in the Antilles gradually emerges as the leading paradigm for today's increasingly transnational subjects: "We are all creoles"; "the world is becoming creolised." In After Empire, Gilroy argues for a new conception of multiculturalism, and subsequently for what he terms a "planetary mentality" in Between Camps (356), echoing Glissant's concept of "worldliness." Hence in the work of both authors, the local becomes the basis for an understanding of modernity at a global level. The oppressed local community, its creolised, diasporic nature being a cause of its own suffering, proves to be the harbinger of a new manner of configuring the dynamics of contemporary societies in their entirety. By forcibly importing that which was outside into Western societies, the creolised citizen gradually hybridises the whole thereby becoming increasingly the rule rather than the exception. Displacement and the absence of unitary points of origin are

8. My own translation of the following: "Nous sommes tous des créoles"; "le monde se créolise" (Introduction à une poétique du divers 55).

9. My own translation of Glissant's neologism “Mondialite”" (Introduction à une poétique du divers 105). 
no longer just the privilege or curse of the diasporic or creolised subject because these characteristics are coming increasingly to be shared by all. And one of the many consequences of this process of social and cultural evolution is that it offers the possibility for an antidote to some of the sufferings of previous generations of diasporic subjects: the "double consciousness" - the concept borrowed from DuBois that the Gilroy of yore was fond of employing - has now become obsolete either because it no longer applies to anyone, or because it increasingly applies to everyone. Either we are all partly Western and also partly not so because our societies as a whole have mutated under the influence of incoming outside influences, or none of us can be categorised in this way precisely because this phenomenon is so generalised that the "double-consciousness" paradigm has ceased to serve any useful function.

I should stress, however, that neither Gilroy nor Glissant views the "mondialite" or the "planetary mentality" of contemporary globalised citizens as being in chime with globalisation when globalisation is viewed as an economic phenomenon. Both Gilroy and Glissant consider economic globalisation to carry with it rather regressive implications. Glissant frequently lamented the tyranny of what he called an Anglo-Saxon led "standardisation" phenomenon (Poétique de la relation 126) which he saw as a cultural consequence of economic hegemony. Gilroy, for his part, hopes that the new multiculturalism he advocates will constitute an extended version of the "counterculture of modernity" he spoke of with respect to the black Atlantic. "Mondialite" and the "planetary mentality" then are intended as politically progressive outlooks, as ways of conceiving of cultural resistance on the part of enlightened subjects to the regressive economically-determined homogenising tendencies which are the fallout from globalisation.

What exactly would a philosophy of "Relation" mean in Gilroy's vision for contemporary cosmopolitanism? What of the multilingualism Glissant insists is the only way forward for the happy coexistence of the diverse societies and cultures around the globe? Is Glissant's conviction defensible that a certain political and philosophical utopianism, of the sort that believes precisely that true multilingualism remains a viable goal in today's world? Gilroy, being an Anglophone, seemingly has little if anything at all to say about the preservation of non-majoritarian languages, and therefore seems to overlook the centrality of the relationship between cultural identity and language. All of his black Atlantic subjects are Anglophones. How do the other concepts in Glissant's sophisticated philosophical apparatus - "errance," "Tout-monde," and his refusal of Western-style system-building, for example - sit with Gilroy's outlook? These are questions one can only speculate about. Within the reciprocal orientation of the two thinkers' broader visions, there remain many contrasts in emphasis, and many slightly different shades of meaning whose incommensurability perhaps ensures that they remain pleasingly and tantalisingly opaque.

Sam CoOMBES

University of Edinburgh

\section{Works Cited}

Anderson, Benedict. Imagined Communities: Reflections on the Origin and Spread of Nationalism. London: Verso, 1983. 
Bongie, C. Friends and Enemies: The Scribal Politics of Post/Colonial Literature. Liverpool: Liverpool UP, 2008.

Chamoiseau, Patrick, and Edouard Guissant. L'Intraitable beauté du monde: Adresse a Barack Obama. Paris: Galaade Editions, 2009.

Dubois, W.E. B. Dusk of Dawn. 1940. Millwood, NY: Kraus-Thomson, 1975.

Gilroy, Paul et al. of the Centre for Contemporary Cultural Studies. The Empire Strikes Back-Race and Racism in '70s Britain. London: Hutchinson, 1982.

- There Ain't No Black in the Union Jack: The Cultural Politics of Race and Nation London: Hutchinson, 1987.

—. The Black. Atlantic. London: Verso, 1993.

—. Small Acts: Thoughts on the Politics of Black Cultures. London: Serpent's Tail, 1993.

-. Between Camps: Race, Identity and Nationalism at the End of the Colour Line. London: Allen Lane, 2000.

—. After Empire: Melancholia or Convivial Culture? London: Routledge, 2004.

Glissant, Edouard. Le Discours Antillais. Paris: Gallimard, 1981.

-. Poetics of Relation. Trans. Betsy Wing. Ann Arbour, MI: U of Michigan P, 1997. Trans. of Poétique de la Relation. Paris: Gallimard, 1990.

—. Introduction à une poétique du divers. Paris: Gallimard, 1996.

—. Traité du Tout-Monde. Paris: Gallimard, 1997. 